\title{
Impairing Powerhouse in Colon Cancer Cells by Hydrazide- Hydrazone-Based Small Molecule
}

\author{
Sohan Patil, ${ }^{\dagger}$ Meenu Mahesh Kuman, ${ }^{\dagger}$ Sandeep Palvai, ${ }^{\dagger}$ Poulomi Sengupta, $^{\dagger}$ and Sudipta Basu ${ }^{*}, \dagger$ \\ ${ }^{\dagger}$ Department of Chemistry, Indian Institute of Science Education and Research (IISER) Pune, Dr. Homi Bhabha Road, Pashan, Pune \\ 411008, India \\ ${ }^{\ddagger}$ Physical Chemistry Division, CSIR-National Chemical Laboratory, Dr. Homi Bhabha Road, Pune 411008, India
}

Supporting Information

\begin{abstract}
Mitochondrion has emerged as one of the unconventional targets in next-generation cancer therapy. Hence, small molecules targeting mitochondria in cancer cells have immense potential in the next-generation anticancer therapeutics. In this report, we have synthesized a library of hydrazide-hydrazone-based small molecules and identified a novel compound that induces mitochondrial outer membrane permeabilization by inhibiting antiapoptotic B-cell CLL/lymphoma 2 (Bcl-2) family proteins followed by sequestration of proapoptotic cytochrome $c$. The new small molecule triggered programmed cell death (early and late apoptosis) through cell cycle arrest in the G2/M phase and caspase-9/3 cleavage in HCT-116 colon cancer cells, confirmed by an array of fluorescence confocal microscopy, cell sorting, and immunoblotting analysis. Furthermore, cell viability studies have verified that the small molecule rendered toxicity to a panel of colon cancer cells (HCT-116, DLD-1, and SW-620), keeping healthy L929 fibroblast cells unharmed. The novel small molecule has the potential to form a new understudied class of mitochondria targeting anticancer agent.
\end{abstract}

\section{INTRODUCTION}

Colon cancer is the third most devastating disease claiming nearly 0.7 million deaths per year globally. ${ }^{1,2}$ Numerous Food and Drug Administration (FDA)-approved small-molecule drugs (5-fluorouracil, oxaliplatin, and irinotecan) are already in clinics for the treatment of colon cancer patients under chemotherapy regimen. ${ }^{3-5}$ However, small-molecule anticancer drugs kill healthy cells along with targeted cancer cells as a collateral damage to induce severe toxic side effects to the patients. Moreover, most of the cancer cells develop resistance mechanisms (intrinsic or extrinsic) to overcome the effect of the drugs. ${ }^{6-9}$ Hence, there is an urgent need to develop novel small molecules to perturb unconventional subcellular targets as the next-generation cancer therapeutics. In recent years, the understanding of biological function beyond ATP (energy currency) generation prompted mitochondrion as an alternative target for anticancer therapy.

Mitochondrion, the powerhouse of the cells, is one of the most important subcellular organelles that contains genomic materials and plays a central role in innumerable cellular processes including bioenergetics, metabolism, biosynthesis, signal transduction, and apoptosis. ${ }^{10-15}$ Subsequently, mitochondrial functions have been altered in different types of cancers $^{16-19}$ making mitochondrion as one of the unorthodox targets for cancer chemotherapy. ${ }^{20-23}$ As a result, several conventional anticancer drugs were routed into mitochondria for improving efficacy, evading drug resistance, and reducing off-target toxicity. ${ }^{24-28}$ Recently, mitochondrion was found to play a crucial role in colon cancer development and progression. ${ }^{29,30}$ Although natural products and synthetic small molecules have evolved as powerful tools to perturb and understand biological phenomena, ${ }^{31-34}$ development of novel small molecules to impair mitochondrial functions selectively in cancer cells, especially in colon cancer, remains a daunting task, ${ }^{35-37}$ hence mostly underexplored.

In recent years, hydrazine, hydrazone, and hydrazide-based compounds having nitrogen-nitrogen $(\mathrm{N}-\mathrm{N})$ bond have emerged as interesting natural and non-natural products. ${ }^{38,39}$ Similarly, hydrazide-hydrazone $(-\mathrm{CO}-\mathrm{NH}-\mathrm{N}=\mathrm{CH}-)$ derivatives (a fusion of hydrazide and hydrazone moieties) demonstrated significant diverse biological effects including anti-inflammatory, antibacterial, antimalarial, and anticancer activities (Scheme 1a). ${ }^{40-46}$ Although hydrazide-hydrazone derivatives have shown immense potential as future anticancer drug candidates, their effect on mitochondrion (intrinsic program cell death mediator) in cancer cells is completely unexplored.

To address this, herein, we illustrate a short and easy synthesis of hydrazide-hydrazone-based library. Screening of the library members in colon cancer cell lines (HCT-116, DLD-

Received: October 9, 2017

Accepted: January 10, 2018

Published: February 2, 2018 
Scheme 1. (a) Chemical Structures, (b) Synthetic Scheme, and (c) Chemical Structure and the ORTEP Diagram ${ }^{a}$
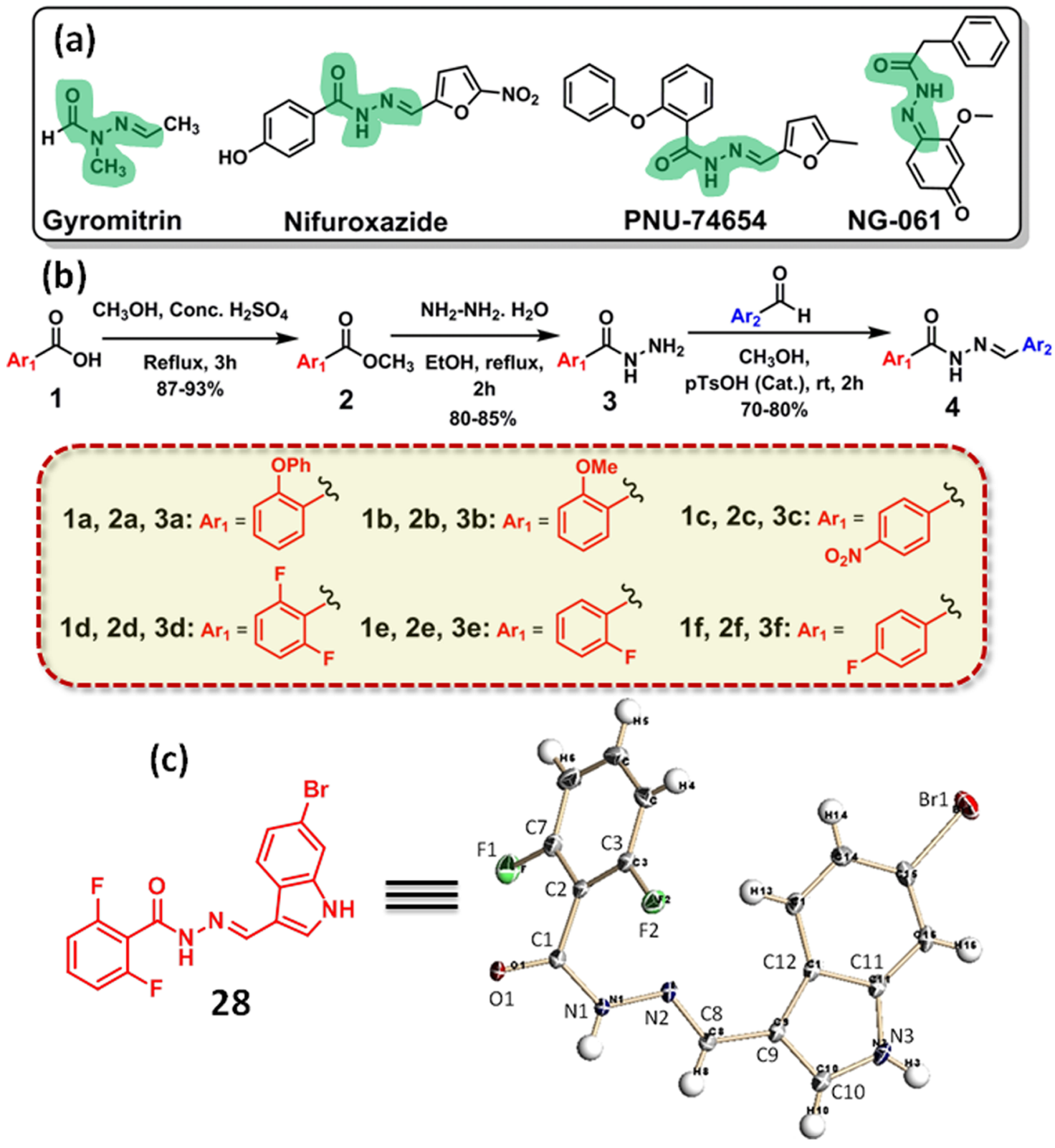

${ }^{a}$ (a) Chemical structures of hydrazide-hydrazone containing biologically active natural products. (b) A synthetic scheme of hydrazide-hydrazonebased small-molecule library. (c) Chemical structure and the ORTEP diagram of compound 28 with $50 \%$ thermal ellipsoids.

1 , and SW-620) yielded a novel small molecule that can damage the mitochondria through $\mathrm{Bcl}-2$ inhibition-mediated outer membrane permeabilization (MOMP). This mitochondrial impairment released cytochrome $c$, generated reactive oxygen species (ROS), and finally induced apoptosis through cell cycle arrest and caspase- $9 / 3$ cleavage.

\section{RESULTS AND DISCUSSION}

2.1. Synthesis of Hydrazide-Hydrazone Library and Characterization. The synthesis of hydrazide-hydrazone library is described in Scheme 1b. First, benzoic acid derivatives $(\mathbf{1} \mathbf{a}-\mathbf{f})$ are reacted with methanol in the presence of concentrated sulfuric acid in refluxing condition to obtain the methyl esters $(\mathbf{2} \mathbf{a}-\mathbf{f})$ in $87-93 \%$ yield. The methyl-benzoate derivatives $(\mathbf{2} \mathbf{a}-\mathbf{f})$ are further reacted with hydrazine monohydrate in ethanol in the refluxing condition to afford benzoic acid-based hydrazides $(3 \mathbf{a}-\mathbf{f})$ in $80-85 \%$ yield (Figure S1). Finally, aromatic hydrazides $(\mathbf{3} \mathbf{a}-\mathbf{f})$ are reacted with aromatic aldehydes in the presence of catalytic $p-\mathrm{TsOH}$ to generate hydrazide-hydrazone derivatives (4) in 70-80\% isolated yield. A library of 30 hydrazide-hydrazone compounds (5-34, Figure S2) is synthesized by this strategy. Chemical structures of all of the library members are confirmed by ${ }^{1} \mathrm{H}$ and ${ }^{13} \mathrm{C}$ NMR and high-resolution mass spectroscopy (HRMS) (Figures S3-S92).

2.2. Screening of Hydrazide-Hydrazones in Colon Cancer Cells. First, the hydrazide-hydrazones are screened to check their ability to induce cell death in colon cancer cells. As there is no previous study of hydrazide-hydrazone derivatives in colon cancer cells, we intend to generate a single-point data using one concentration for each compound in a highthroughput screening method. ${ }^{47,48}$ We choose a high initial 


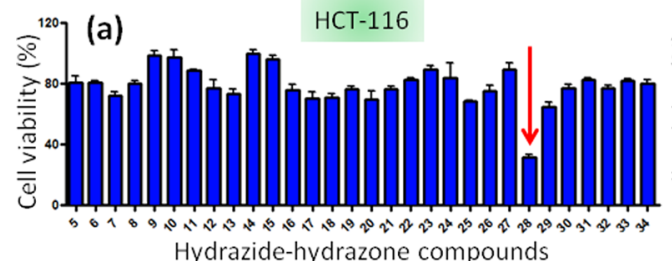

Hydrazide-hydrazone compounds

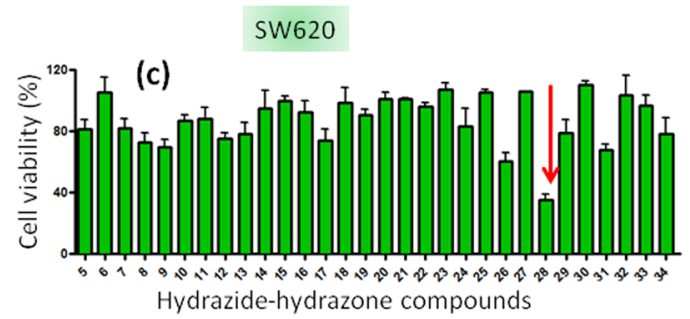

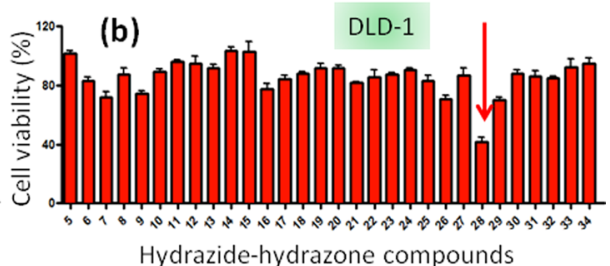

(d)

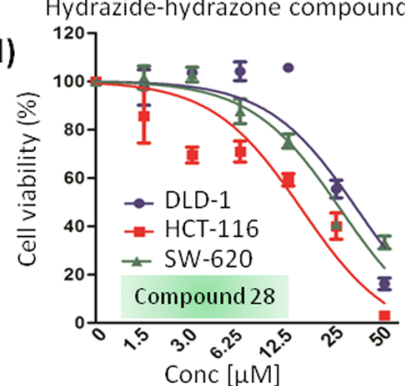

Figure 1. MTT assay of hydrazide-hydrazone derivatives in (a) HCT-116, (b) DLD-1, and (c) SW-620 cells at $30 \mu \mathrm{M}$ concentration after 24 h of incubation. (d) Dose-dependent cell viability assay of compound 28 in HCT-116, DLD-1, and SW-620 cells at 24 h after incubation.

concentration $(30 \mu \mathrm{M})$ to avoid false-negative and false-positive hits at lower concentration. Moreover, the nontoxic molecules in high concentration should be easily eliminated for further studies. Hence, HCT-116, DLD-1, and SW-620 colon cancer cells are treated with hydrazide-hydrazone derivatives at 30 $\mu \mathrm{M}$ concentration and the cell viability is assessed by 3-(4,5dimethylthiazol-2-yl)-2,5-diphenyltetrazolium bromide (MTT) assay at $24 \mathrm{~h}$ after incubation. Interestingly, it was found that only compound 28 (Scheme 1c, Figure S2) induces $31.7 \pm 1.7$, $41.7 \pm 3$, and $35.4 \pm 3.4 \%$ cell viability in HCT-116, DLD-1, and SW-620 cells, respectively, at $30 \mu \mathrm{M}$ concentrations (Figure $1 \mathrm{a}-\mathrm{c}$ ). The rest of the library members show negligible cell death even at $30 \mu \mathrm{M}$ after $24 \mathrm{~h}$.

The dose-dependent cytotoxicity of compound $\mathbf{2 8}$ is estimated further in HCT-116, DLD-1, and SW-620 cells by MTT assay $24 \mathrm{~h}$ after incubation. Compound 28 demonstrates $\mathrm{IC}_{50}=20.0 \pm 2.7,27.7 \pm 1.8$, and $20.5 \pm 0.5 \mu \mathrm{M}$ (with cell viability $=3.15 \pm 0.9,16.2 \pm 2.4$, and $33.3 \pm 2.6 \%$ at $50 \mu \mathrm{M})$ in HCT-116, DLD-1, and SW-620 cells, respectively (Figure 1d). To compare the potential of compound $\mathbf{2 8}$ to induce cell death in colon cancer cells with other traditional chemotherapeutic drugs used in clinics, we treat HCT-116 cells with 5-fluorouracil (5-FU), camptothecin, and cisplatin in a dose-dependent manner for $24 \mathrm{~h}$ and evaluate the cell viability by the MTT assay. Interestingly, it is observed that 5-FU, camptothecin, and cisplatin show a much higher $\mathrm{IC}_{50}=57.3 \pm 3.6 \mu \mathrm{M}$ (cell viability $=57.3 \pm 3.6 \%$ at $50 \mu \mathrm{M}$ ), $44.5 \pm 2.9 \mu \mathrm{M}$ (cell viability $=44.5 \pm 2.9 \%$ at $50 \mu \mathrm{M}$ ), and $24.6 \pm 0.5 \mu \mathrm{M}$ (cell viability $=$ $33.9 \pm 1.8 \%$ at $50 \mu \mathrm{M}$ ), respectively (Figure S93). Furthermore, we want to check if the dissociation components of compound $\mathbf{2 8}$ in the acidic medium can induce cellular toxicity. Hence, HCT-116 cells are treated with 2,6difluorobenzohydrazide (3d in Figure $\mathrm{S} 1$ ) and 6-bromo- $1 \mathrm{H}$ indole-3-carbaldehyde in a dose-dependent manner for $24 \mathrm{~h}$, and the cell viability is measured by the MTT assay. It is observed that both compounds show negligible toxicity (Figure S94) toward HCT-116 cells.

One of the major challenges in the current cancer therapy is to target cancer cells selectively while keeping normal healthy cells unperturbed. To evaluate the effect in healthy cells, we treat L929 fibroblast cells with compound $\mathbf{2 8}$ in a dosedependent manner at $24 \mathrm{~h}$ after incubation. The cell viability is measured by the MTT assay. Interestingly, compound $\mathbf{2 8}$ shows almost no toxicity (cell viability $=96.67 \pm 6.3 \%, n=3$, mean \pm SEM) to L929 cells even at a higher concentration of $100 \mu \mathrm{M}$ (Figure S95). On the other hand, cisplatin, camptothecin, and 5-FU shows dose-dependent toxicity in L929 with $78.3,63.5$, and $72.0 \%$ cell viability, respectively, at $100 \mu \mathrm{M}$ concentration at $24 \mathrm{~h}$ after incubation (Figure S96). These MTT assays provide a convincing evidence that compound 28 can kill colon cancer cells much efficiently compared to clinically approved traditional cytotoxic drugs while keeping healthy cells unharmed.

We further characterize the structure of the lead compound 28 by X-ray crystallography (Scheme 1c). The purity of compound 28 is also evaluated to be $98.6 \%$ by highperformance liquid chromatography (HPLC, Figure S97). The hydrazone and hydrazide functionalities are known to be labile in an acidic medium. ${ }^{49}$ Hence, to be successful in targeting subcellular organelles in colon cancer, compound $\mathbf{2 8}$ should be stable in an acidic tumor environment. The stability of compound $\mathbf{2 8}$ in an acidic medium is further evaluated. Compound 28 is incubated in $\mathrm{pH}=5.5$ buffer for short $(24 \mathrm{~h})$ and longer $(72 \mathrm{~h})$ time, and its integrity is confirmed by matrixassisted laser desorption ionization time-of-flight (MALDITOF). From the MALDI-TOF spectroscopy (Figures S98 and S99), the fact that compound $\mathbf{2 8}$ remains stable in an acidic milieu even after $72 \mathrm{~h}$ indicates its potential for therapeutic application in cancer.

2.3. Mitochondrial Outer Membrane Permeabilization (MOMP). One of the hallmarks of cancer cells is to resist cellular death. ${ }^{50,51}$ Mitochondria play a crucial role in controlling cancer cell death by inducing mitochondrial outer membrane permeabilization (MOMP) ${ }^{15,52-54}$ To evaluate the effect of compound $\mathbf{2 8}$ on mitochondria in colon cancer cells, the mitochondrial membrane potential $\left(\Delta \psi_{\mathrm{m}}\right)$ is investigated

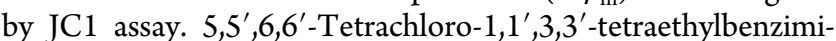
dazolocarbocyanine iodide (JC1), a cationic carbocyanine dye, shows membrane potential-dependent homing into mitochondria with a switch from green $(\sim 525 \mathrm{~nm})$ to red $(\sim 590 \mathrm{~nm})$ in fluorescence emission by forming J-aggregates (red fluorescence) in a higher concentration. We estimate the mitochondrial membrane permeabilization by the increase in green/red fluorescent intensity ratio. ${ }^{55}$ HCT-116 cells are treated with 

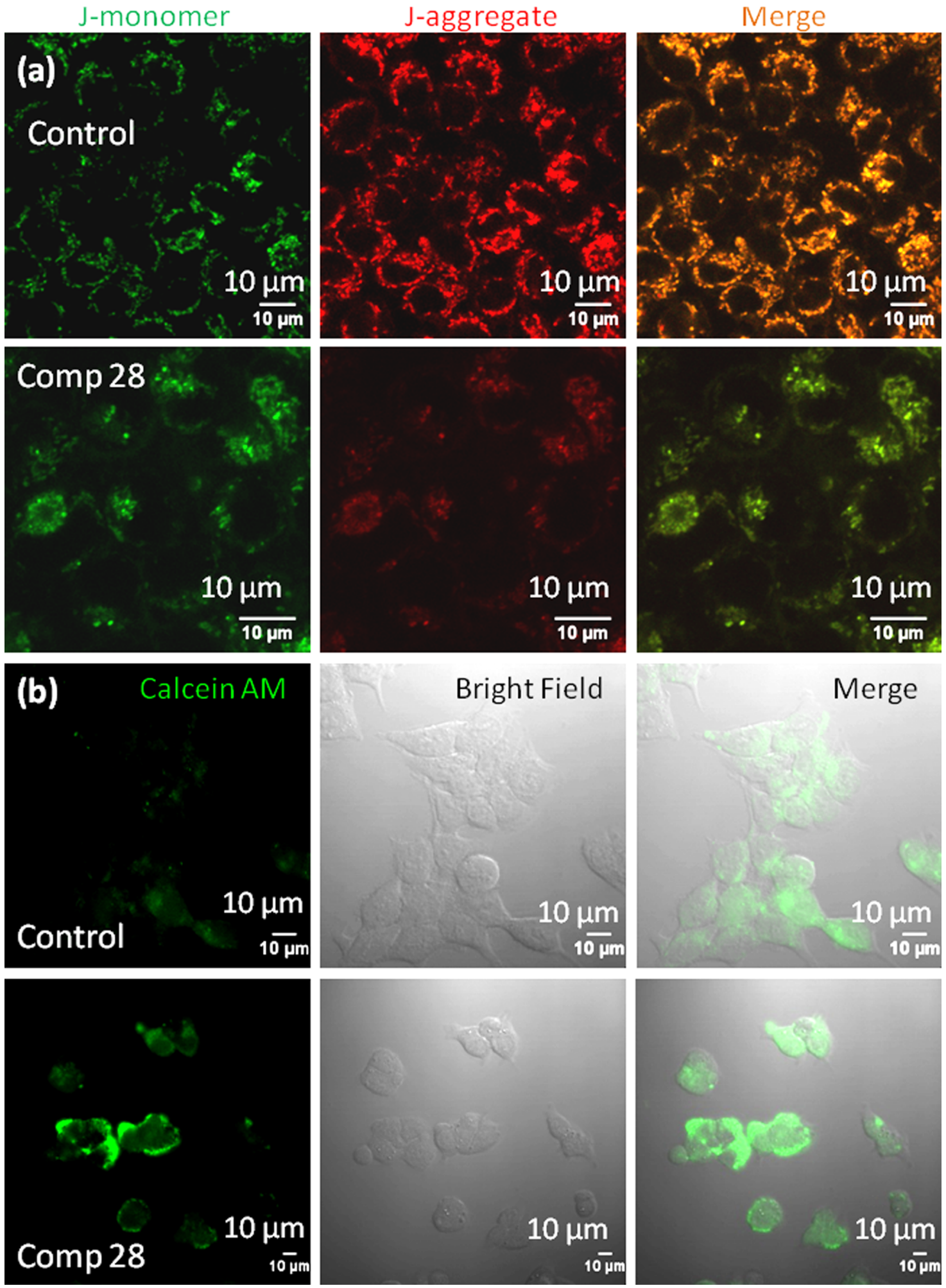

Figure 2. Confocal microscopy images of HCT-116 cells treated with compound $\mathbf{2 8}$ followed by (a) JC1 staining to observe mitochondrial outer membrane permeabilization (MOMP) and (b) calcein acetoxymethyl ester (AM) staining to observe mitochondrial transition pore opening (MTPs). Scale bar $=10 \mu \mathrm{m}$.

compound 28 at $15 \mu \mathrm{M}$ (sub-IC $\mathrm{I}_{50}$ concentration to avoid cell death, stress response, and morphology change) for $24 \mathrm{~h}$ and the cells stained with the JC1 dye. Confocal laser scanning microscopy (CLSM) is performed to visualize the live stained cells. Figure 2a shows that cells treated with compound $\mathbf{2 8}$ induce a significant increase in the green/red ratio (green/red =
$1.06 \pm 0.2)$ compared to control nontreated cells (green/red = $0.51 \pm 0.2$ ) (Figure S100). This confocal microscopy of JC1 assay confirms that compound $\mathbf{2 8}$ induces mitochondrial membrane permeabilization.

2.4. Mitochondrial Transition Pore (MTP) Formation. Mitochondrial outer membrane permeabilization leads to the 

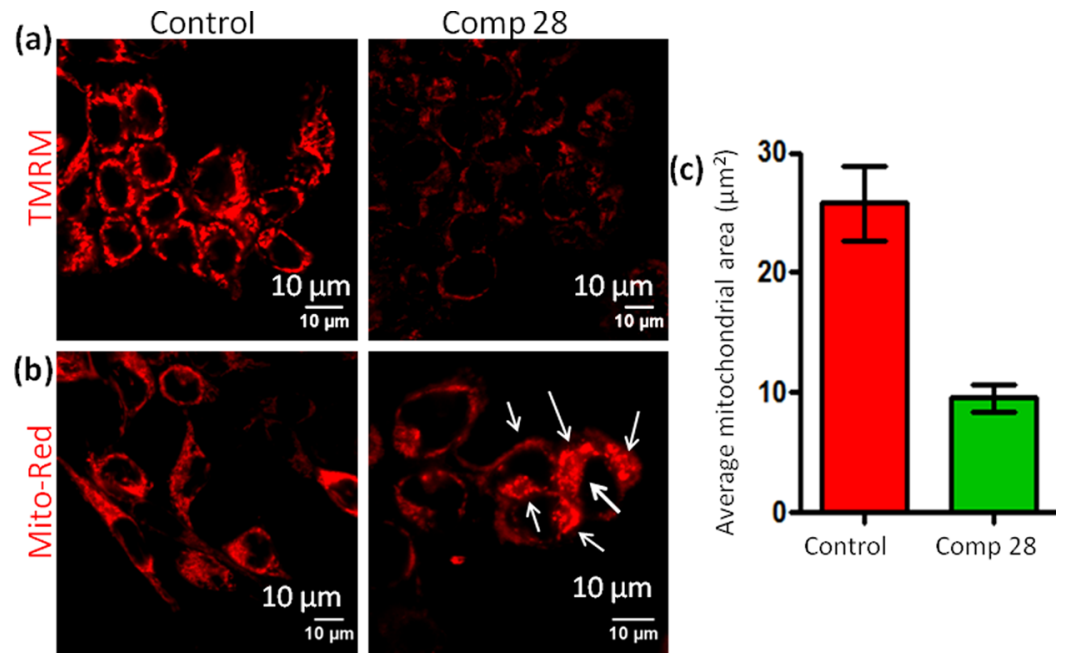

Figure 3. Confocal microscopy images of HCT-116 cells treated with compound $\mathbf{2 8}$ followed by (a) staining with red fluorescent TMRM to evaluate mitochondrial depolarization after treatment with compound 28 and (b) MitoTracker Red CMXRos to observe damaged mitochondrial morphology. Scale bar $=10 \mu \mathrm{m}$. (c) Quantification of mitochondrial area after treatment with compound 28 determined from CLSM using MitoMorphology macro and ImageJ analysis software.

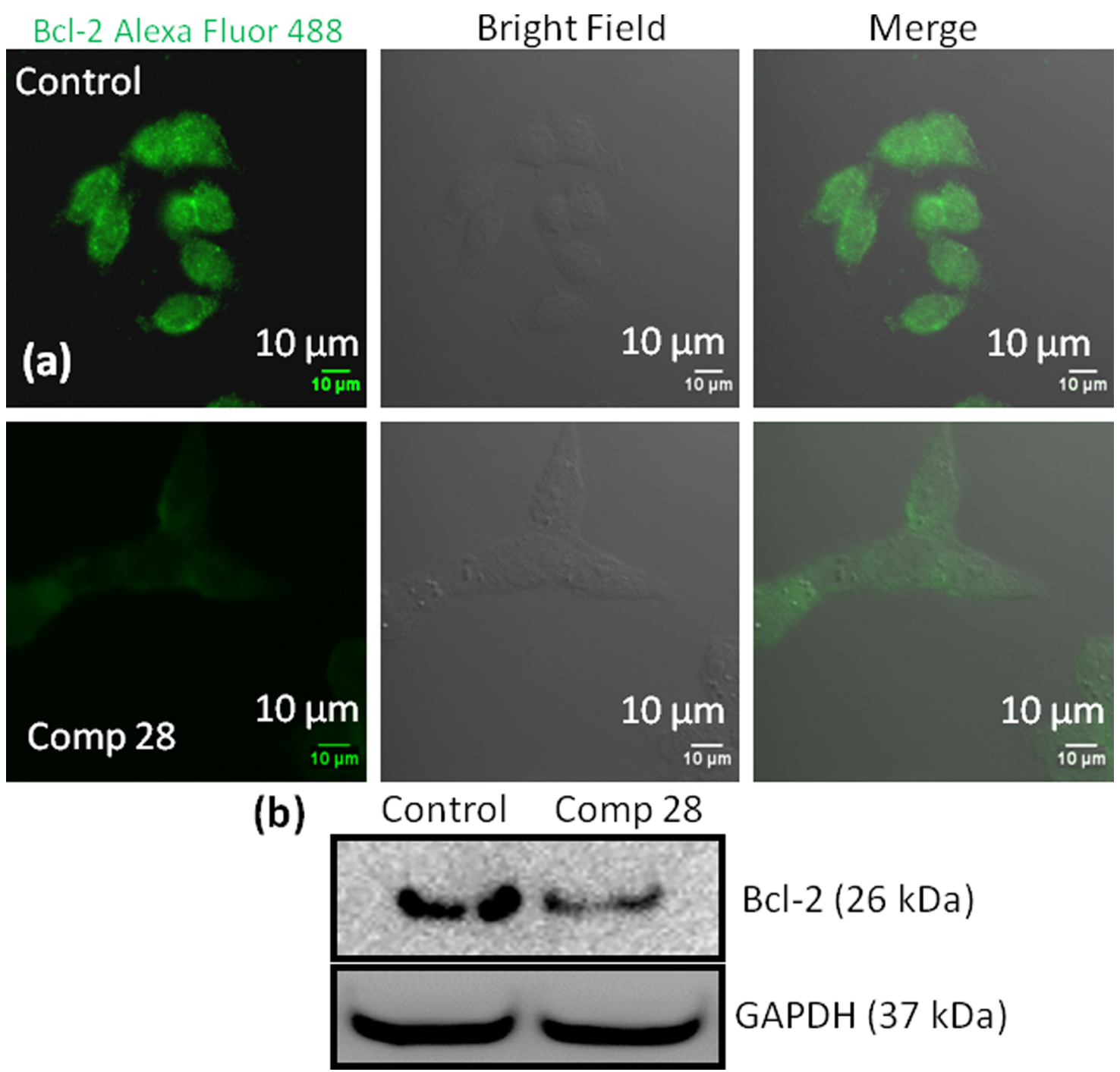

Figure 4. (a) Confocal microscopy images of HCT-116 cells treated with compound 28 followed by staining with green fluorescent Alexa Fluor 488 labeled Bcl-2 antibody. Scale bar $=10 \mu \mathrm{m}$. (b) Western blot analysis to evaluate cytochrome $c$ expression in HCT-116 cells after treatment with compound 28 for $24 \mathrm{~h}$. 

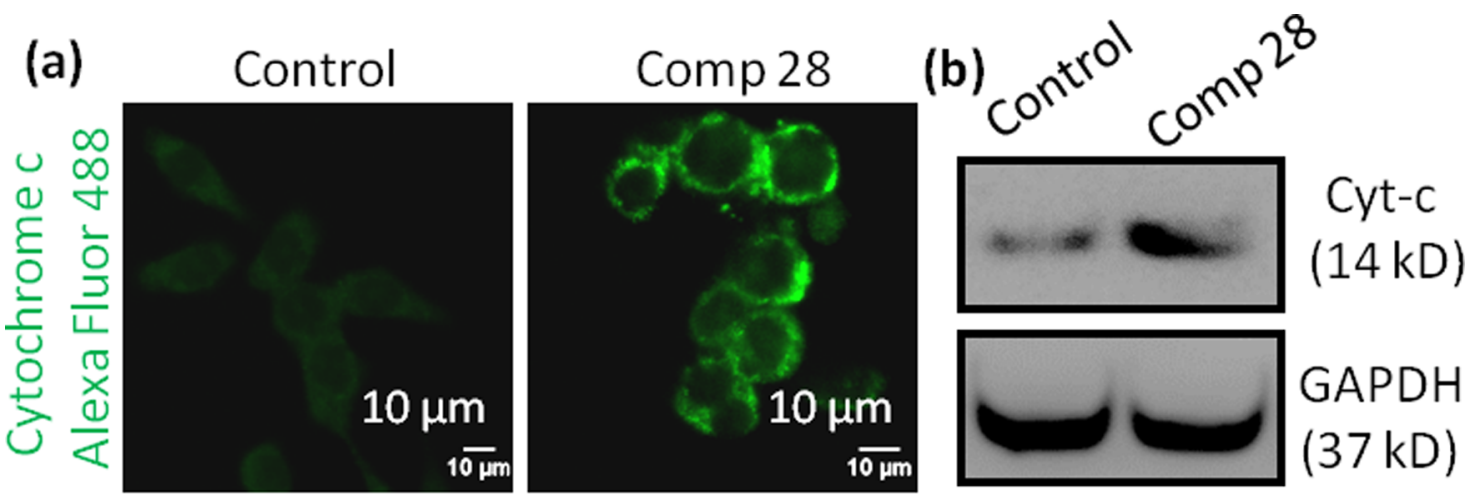

(c)

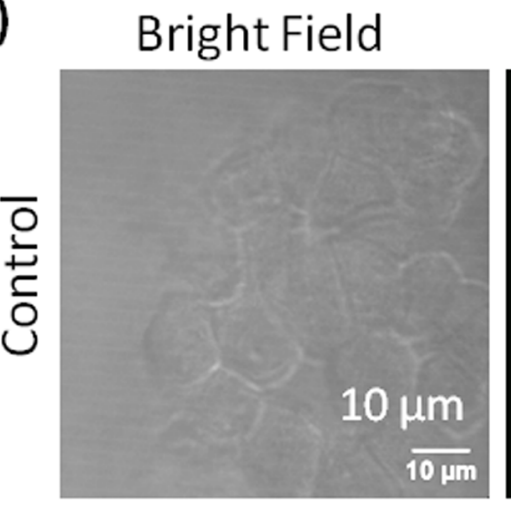

DCF (ROS)
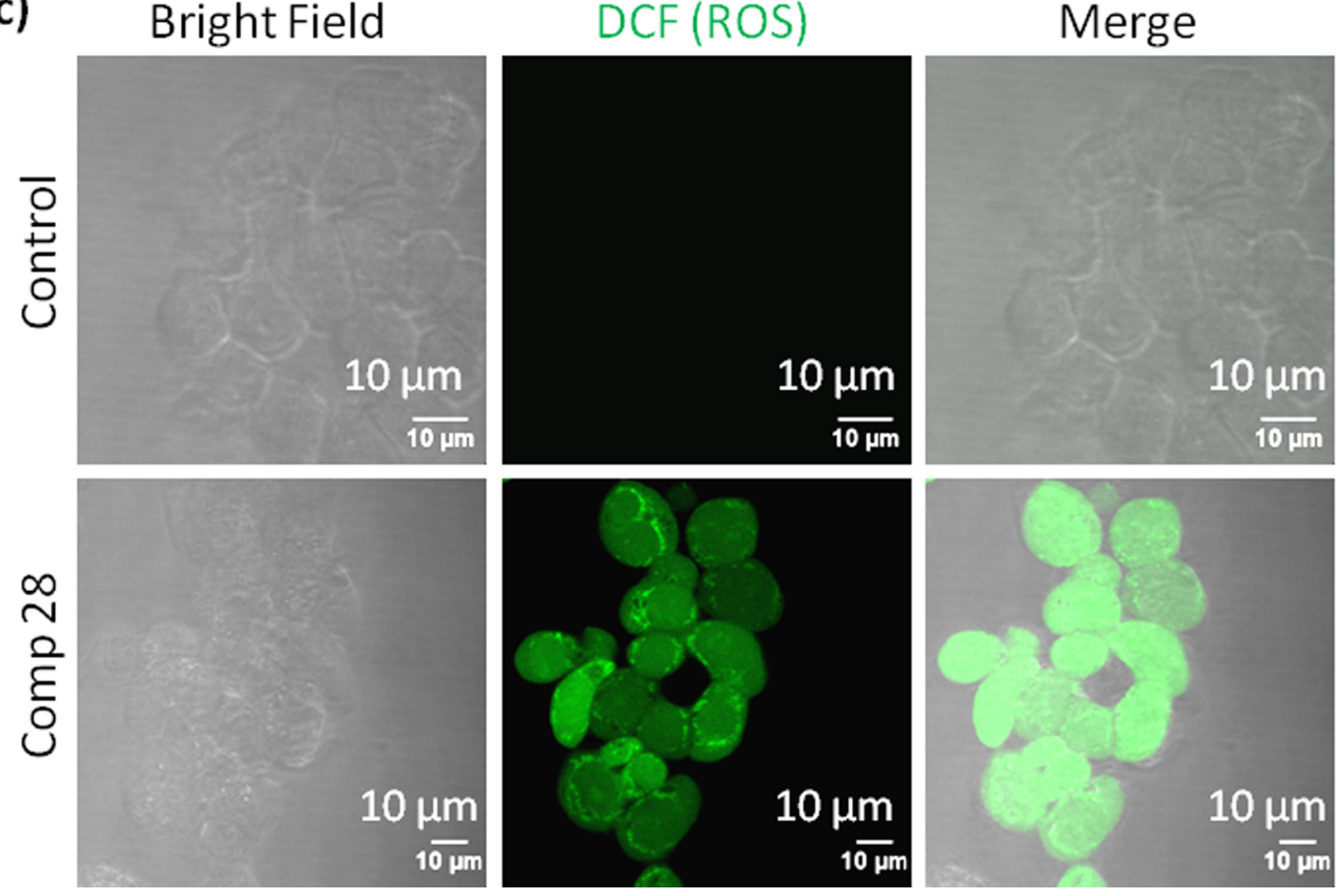

Figure 5. (a) Confocal images of HCT-116 cells treated with compound 28 for 24 h. Cells were stained with green fluorescent Alexa Fluor 488 labeled cytochrome $c$ antibody. (b) Western blot analysis to evaluate cytochrome $c$ expression in HCT-116 cells after treatment with compound 28 for $24 \mathrm{~h}$. (c) Confocal images of HCT-116 cells stained with $2^{\prime}, 7^{\prime}$-dichlorodihydrofluorescein diacetate $\left(\mathrm{H}_{2} \mathrm{DCFDA}\right)$ to observe reactive oxygen species (ROS) generated by compound 28 at $24 \mathrm{~h}$ after incubation. Scale bar $=10 \mu \mathrm{m}$.

opening of mitochondrial transition pores (MTPs). Further opening of the MTPs is assessed by calcein acetoxymethyl ester (calcein AM) assay, where calcein AM penetrates into the cells and homes into cytosol and mitochondria. ${ }^{56}$ Subcellular esterases cleave acetoxymethyl esters into acid functionality to release green fluorescent calcein, which is quenched with the externally added $\mathrm{CoCl}_{2}$ while keeping the mitochondrial calcein AM unperturbed. However, upon opening MTPs, the mitochondrial calcein AM will be sequestered into cytosol, leading to the production of green fluorescent calcein. To evaluate MTP formation, HCT-116 cells are treated with compound 28 for $24 \mathrm{~h}$ and stained with calcein $\mathrm{AM}$ and $\mathrm{CoCl}_{2}$. As the control, HCT-116 cells are treated with only calcein AM and $\mathrm{CoCl}_{2}$ without compound 28. Live cells are further imaged with CLSM. Figure $2 \mathrm{~b}$ confirms that compound $\mathbf{2 8}$ significantly increases the sequestration of green fluorescent calcein in cytosol compared to the control cells. This calcein AM assay evidently validates that compound $\mathbf{2 8}$ damages mitochondria and opens up MTPs in HCT-116 colon cancer cells.
2.5. Induction of Mitochondrial Damage. Mitochondrial outer membrane polarization and transition pore formation diminish mitochondrial hyperpolarization. To evaluate whether compound 28 can reinstate the hyperpolarization of HCT-116 cells, we perform tetramethylrhodamine methyl ester (TMRM) assay. ${ }^{57}$ Ideally, cancer cells acquire significantly higher hyperpolarized $\Delta \psi_{\mathrm{m}}$, leading to the accumulation of red fluorescent TMRM in control cells. However, compound $\mathbf{2 8}$ $(15 \mu \mathrm{M})$ treatment for $24 \mathrm{~h}$ reverses the mitochondrial hyperpolarization, leading to an efflux of TMRM from HCT116 cells. As a result, a significant reduction in red fluorescent intensity is observed by CLSM (Figure 3a). The transition pore opening and reduction of $\Delta \psi_{\mathrm{m}}$ mediated by mitochondrial outer membrane permeabilization (MOMP) leads to mitochondrial structural damage.

We further estimate the damage to the mitochondrial morphology induced by compound 28 . HCT-116 cells are treated with compound $28(15 \mu \mathrm{M})$ for $24 \mathrm{~h}$ and mitochondria are stained with MitoTracker Red CMXRos. Confocal microscopy images in Figure $3 \mathrm{~b}$ exhibit that elongated healthy 

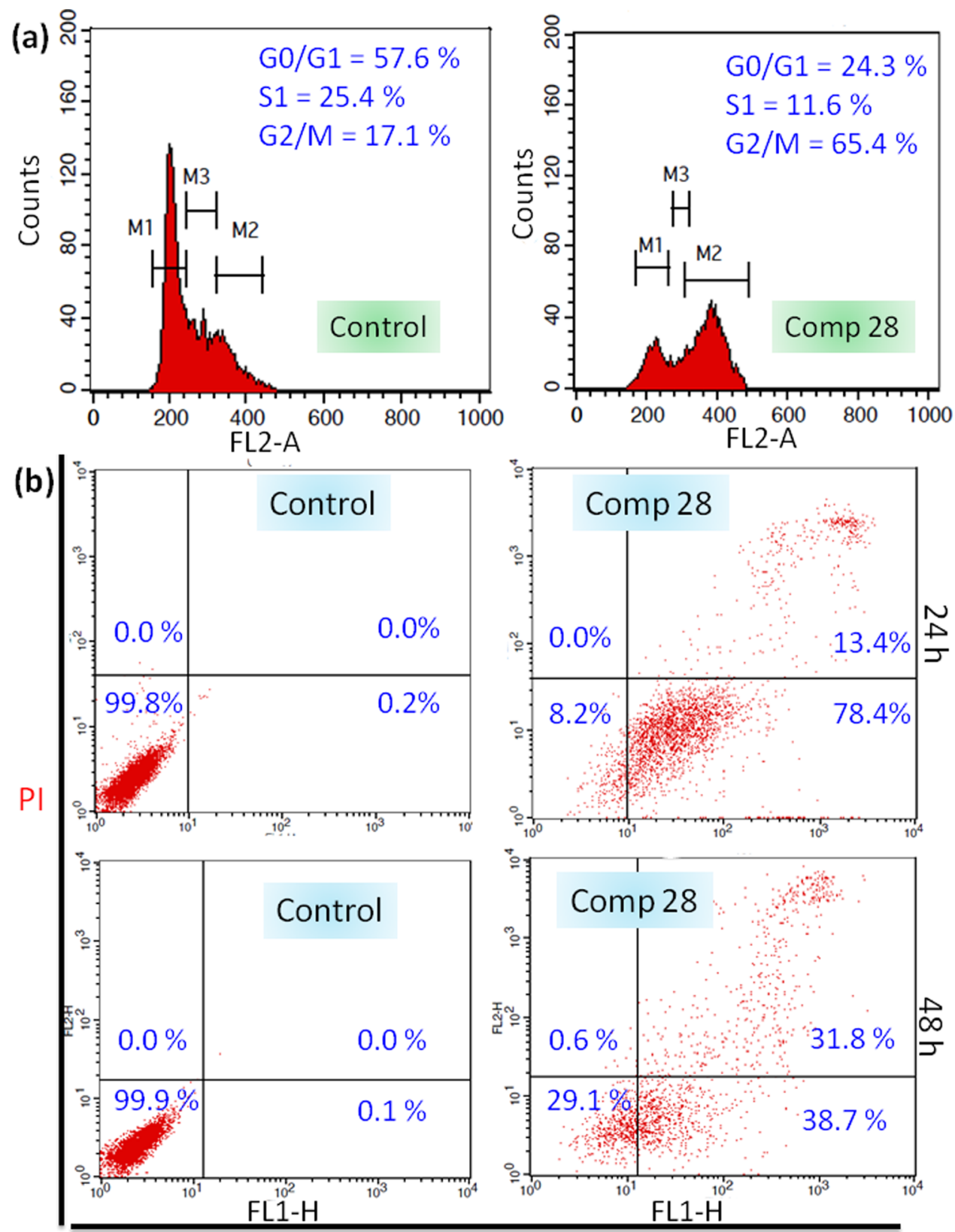

Annexin V-FITC

Figure 6. (a) Cell cycle analysis by staining the DNA in HCT-116 cells with PI at $24 \mathrm{~h}$ after incubation with compound 28. (b) Flow cytometry analysis of HCT-116 cells after treatment with compound 28 for 24 and 48 h to observe apoptosis (lower left, lower right, upper left, and upper right quadrants represent healthy, early apoptotic, necrotic, and late apoptotic cells, respectively).

mitochondrial morphology is visibly disrupted into punctated structure (shown by white arrows), leading to mitochondrial damage by compound $\mathbf{2 8}$ treatments. Further quantification of the average mitochondrial area is performed by MitoMorphology macro, which measures mitochondrial elongation and morphology from confocal images through an Image analysis software. ${ }^{58}$ Mitochondrial average area for HCT-116 cells treated with compound $\mathbf{2 8}$ is found to be significantly less $\left(9.54 \pm 0.6 \mu \mathrm{m}^{2}, n=3\right.$, mean \pm SEM) compared to the average mitochondrial area in control cells $\left(25.8 \pm 1.8 \mu \mathrm{m}^{2}, n=3\right.$, mean \pm SEM) (Figure 3c). These confocal microscopy images clearly demonstrate that compound $\mathbf{2 8}$ damages mitochondria by inducing MOMP.
2.6. Bcl-2 Inhibition. MOMP is tightly controlled by the Bcl-2 (B-cell CLL/lymphoma 2) family proteins. ${ }^{53}$ As a result, small molecules inhibiting $\mathrm{Bcl}-2$ proteins have emerged as potent anticancer drugs. ${ }^{59}$ To evaluate the effect on $\mathrm{Bcl}-2$, we treat HCT-116 cells with compound 28 for $24 \mathrm{~h}$, and Bcl-2 protein is stained with a green fluorescent Alexa Fluor 488 labeled antibody. The CLSM images in Figures 4a and S101 confirm that compound $\mathbf{2 8}$ inhibits the expression of Bcl-2 proteins compared to nontreated control cells. Furthermore, we estimate the expression of Bcl-2 by western blot analysis. HCT116 cells are treated with compound 28 , and the expression of $\mathrm{Bcl}-2$ protein is visualized by gel electrophoresis. Figure $4 \mathrm{~b}$ shows that compound $\mathbf{2 8}$ reduces the expression of Bcl-2 protein significantly compared to nontreated control cells. We 
also quantify the expression of $\mathrm{Bcl}-2$ from gel electrophoresis by normalizing the respective GAPDH expression. It is observed that compound $\mathbf{2 8}$ reduces the expression of Bcl-2 1.2-fold compared to control cells (Figure S102). These confocal microscopy and protein expression from western blotting experiments confirm that compound $\mathbf{2 8}$ induces mitochondrial damage by inhibiting $\mathrm{Bcl}-2$ proteins on the mitochondrial outer membrane.

2.7. Cytochrome c Release. Mitochondrial damage directs the translocation of proapoptotic cytochrome $c$ from mitochondria into the cytosol to trigger a programmed cell death. ${ }^{15,60}$ To visualize the expression of cytochrome $c$, HCT116 cells are treated with compound $28(15 \mu \mathrm{M})$ for $24 \mathrm{~h}$ and cytochrome $c$ is stained with antibody tagged with green fluorescent Alexa Fluor 488. The confocal images (Figure 5a) evidently confirm that compound $\mathbf{2 8}$ induces a significantly increased cytochrome $c$ in cytosol compared to nontreated control cells. Further, expression of cytochrome $c$ is determined by western blot analysis after treatment of HCT-116 cells with compound $28(15 \mu \mathrm{M})$ for $24 \mathrm{~h}$. Gel electrophoresis images (Figure 5b) demonstrate a significant increase in the expression of cytochrome $c$ in cells treated with compound 28 compared to control cells. We also quantify the expression of cytochrome $c$ from the western blot. It is found that compound 28 treatment increases cytochrome $c$ expression by 2.2 -fold compared to the control cells (Figure S103). These confocal images and gel electrophoresis assays demonstrate that compound $\mathbf{2 8}$ induces the release of proapoptotic cytochrome $c$ after mitochondrial damage.

2.8. Reactive Oxygen Species (ROS) Generation. One of the hallmarks of mitochondrial damage through MOMP is the production of reactive oxygen species (ROS). ${ }^{15} \mathrm{We}$ evaluate the MOMP-mediated ROS generation by cellpermeable $2^{\prime}, 7^{\prime}$-dichlorodihydrofluorescein diacetate ( $\mathrm{H}_{2}$ DCFDA) assay. ${ }^{61} \mathrm{H}_{2}$ DCFDA is a nonfluorescent probe, which upon cellular internalization, gets hydrolyzed by esterases followed by oxidation by reactive oxygen species (ROS) to generate green fluorescent $2^{\prime}, 7^{\prime}$-dichlorofluorescein (DCF). To evaluate the ROS generation, HCT-116 cells are incubated with compound $28(15 \mu \mathrm{M})$ for $24 \mathrm{~h}$ followed by staining the cells with $\mathrm{H}_{2}$ DCFDA. The live cells are visualized by confocal microscopy. Figure 5c unmistakably demonstrates that cells treated with compound $\mathbf{2 8}$ generates a significantly increased ROS, leading to the production of a much improved green fluorescent DCF compared to control cells. These CLSM images indicate that compound $\mathbf{2 8}$ generates ROS through mitochondrial damage.

2.9. Cell Cycle Arrest and Apoptosis Induction. Mitochondrial damage, followed by the production of proapoptotic cytochrome $c$ and ROS, instigates cell cycle arrest before apoptosis. ${ }^{62}$ We measure the cell cycle arrest induced by compound 28 by fluorescence-activated cell-sorting (FACS) analysis. HCT-116 cells are incubated with compound 28 (15 $\mu \mathrm{M})$ for $24 \mathrm{~h}$ and cell cycle arrest is analyzed by propidium iodide (PI)-labeled DNA. Flow cytometric analysis reveals that compound 28 treatment leads to $24.3,11.6$, and $65.4 \%$ cells into G0/G1, S1, and G2/M phase, respectively (Figure 6a). In contrast, 57.6, 25.4, and only $17.1 \%$ cells are found in G0/G1, $\mathrm{S} 1$, and G2/M phase, respectively, in nontreated control cells. These FACS analyses show evidently that compound $\mathbf{2 8}$ arrests HCT-116 cells into the G2/M phase.

Subsequently, cell cycle arrest pushes the cells into programmed cell death or apoptosis. ${ }^{62}$ We further evaluate the induction of apoptosis by FACS analysis. HCT-116 cells are treated with compound $28(15 \mu \mathrm{M})$ for 24 and $48 \mathrm{~h}$ followed by staining apoptotic and necrotic cells by green fluorescent fluorescein isothiocyanate (FITC)-labeled annexin V (staining the flipped phosphatidylserine at the outer surface of apoptotic cells) and red fluorescent PI (staining the DNA of the late apoptotic and necrotic cells), respectively. After $24 \mathrm{~h}$, with compound 28 treatment 78.4 and $13.4 \%$ cells are found in early and late apoptosis stages respectively (Figure $6 \mathrm{~b}$, upper panel). In comparison, only 0.2 and $0 \%$ cells are found in early and late apoptotic stages, respectively, in control cells. Similarly, at $48 \mathrm{~h}$ after incubation, 38.7 and $31.8 \%$ cells are observed in early and late apoptotic stages in compound $\mathbf{2 8}$ treatments, respectively (Figure $6 \mathrm{~b}$, lower panel). We anticipate that prolonged exposure of colon cancer cells to mitochondria-damaging compound 28 shifts the programmed cell death from early to late stages of apoptosis. These FACS analyses demonstrate that compound 28 induces apoptosis in colon cancer cells through mitochondrial damage.

2.10. Caspase-9/3 and p53 Expression. Induction of apoptosis in cancer cells activates the initiator caspase-9, which further activates the activator caspase- 3 after cleavage. ${ }^{63,64}$ We estimate the expression of caspase- 9 and caspase- 3 by western blot analysis in HCT-116 cells at $24 \mathrm{~h}$ after incubation with compound $28(15 \mu \mathrm{M})$. Gel electrophoresis reveals that compound 28 triggered the cleavage of caspase- 9 and caspase- 3 compared to control cells (Figure 7a). Further quantification

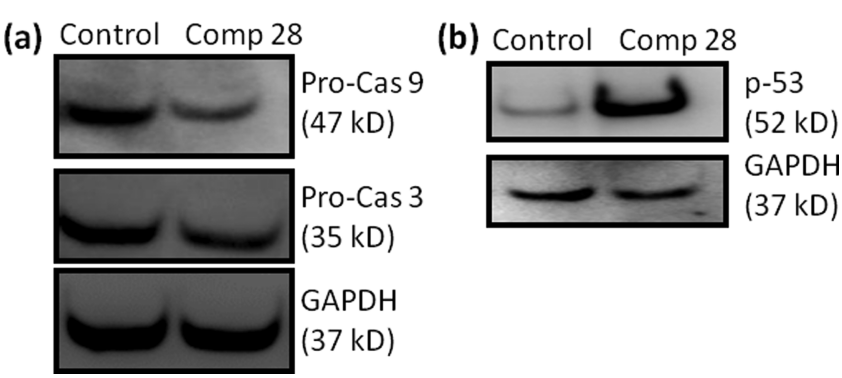

Figure 7. (a) Western blot analysis to observe the expression of (a) procaspase-9, procaspase- 3 , and (b) p-53 in HCT-116 cells after treatment with compound 28 for $24 \mathrm{~h}$.

from western blot shows that compound $\mathbf{2 8}$ reduces the expression of caspase- 3 and caspase- 9 by 1.6 - and 2.5 -folds, respectively (Figure S104a). These gel electrophoresis studies undoubtedly exhibit that compound $\mathbf{2 8}$ induced apoptosis in HCT-116 cells through the cleavage of caspase- 9 and caspase- 3 .

Mitochondria-mediated apoptosis is highly dependent on p53 protein, which is one of the most important tumor suppressors. ${ }^{65}$ Moreover, $\mathrm{Bcl}-2$ inhibition on mitochondria in colon cancer triggers the cells into p53-driven apoptosis. ${ }^{66}$ Hence, we further evaluate the expression of p53 in mitochondrial damage mediated by compound 28 , followed by apoptosis. We treat HCT-116 cells with compound 28 (15 $\mu \mathrm{M})$ for $24 \mathrm{~h}$ and assess the expression of $\mathrm{p} 53$ by western blot analysis. The gel electrophoresis image in Figure $7 \mathrm{~b}$ confirms that compound $\mathbf{2 8}$ remarkably increases the expression of p53 compared to control cells. Further quantification from gel electrophoresis shows that compound $\mathbf{2 8}$ increases the expression of p53 in HCT-116 cells 14.7-folds compared to control cells (Figure S104b). 


\section{CONCLUSIONS}

In conclusion, this report describes a straightforward and concise synthesis of natural product-guided hydrazidehydrazone-based small-molecule library. One of the library members was discovered to impair mitochondria by disrupting outer membrane through the inhibition of $\mathrm{Bcl}-2$ protein followed by production of reactive oxygen species. This small molecule blocked the cell cycle in $\mathrm{G} 2 / \mathrm{M}$ phase, cleaved caspase- $9 / 3$, and increased p53 to stimulate programmed cell death in colon cancer cells. This hydrazide-hydrazone-based small molecule showed remarkable efficacy in a panel of colon cancer cell lines, without collateral toxicity in healthy cells. We anticipated this novel small molecule had the potential to become a tool to illuminate mitochondrial biology and further optimization studies need to be performed for translating it successfully into clinics as an anticancer agent.

\section{MATERIALS AND METHODS}

4.1. Materials. Commercially available chemicals and solvents were used without further purification and distillation. Chemical reactions were carried out without any inert gas condition. Precoated silica gel aluminum sheets $60 \mathrm{~F}_{254}$ for analytical thin-layer chromatography (TLC) were obtained from EMD Millipore Laboratories. Cell culture media (Dulbecco's modified Eagle's medium (DMEM)) and 3-(4,5dimethylthiazol-2-yl)-2,5-diphenyltetrazolium bromide (MTT) were purchased from HiMedia. Sodium dodecyl sulfate (SDS), Hanks' balanced salts, $N$-(2-hydroxyethyl)piperazine- $N$-ethanesulfonic acid sodium salt, propidium iodide, calcein AM, Annexin V-FITC Staining Kit and $2^{\prime}, 7^{\prime}$-dichlorofluoresceindiacetate (DCFH-DA) were obtained from Sigma-Aldrich. MitoTracker Red CMXRos and tetramethylrhodamine methyl ester perchlorate (TMRM) were purchased from Thermo Fisher Scientific. All of the primary and secondary antibodies were obtained from Cell Signaling Technology, Biolegend, and Abcam. Confocal laser scanning microscopy was performed by a Zeiss LSM 710 machine. Flow cytometry analysis was performed using a BD FACS Calibur flow cytometer. Each sample was done in triplicate.

4.2. General Procedure for the Synthesis of Benzoic Acid Methyl Esters ( $2 \mathrm{a}-\mathrm{f})$. Substituted benzoic acids $(0.5 \mathrm{~g})$ were dissolved in absolute methanol $(8 \mathrm{~mL})$, followed by the addition of concentrated sulfuric acid $(0.3 \mathrm{~mL})$. The reaction mixture was refluxed, and the progress of the reaction was monitored by thin-layer chromatography (TLC). After completion of the reaction, methanol was evaporated under reduced pressure. To the residue aqueous $10 \%$ sodium bicarbonate $\left(\mathrm{NaHCO}_{3}\right)(15 \mathrm{~mL})$ was added, extracted with ethyl acetate $(3 \times 20 \mathrm{~mL})$, and washed with saturated $\mathrm{NaCl}$ solution $(2 \times 10 \mathrm{~mL})$. The organic layer was dried over anhydrous $\mathrm{Na}_{2} \mathrm{SO}_{4}$ and the organic solvent was evaporated to get methyl esters of substituted benzoic acid in $87-93 \%$ yield as a light yellow viscous liquid.

4.3. General Procedure for the Synthesis of Benzoic Acid Hydrazides ( $3 a-f)$. Substituted benzoic acid methyl esters $(\mathbf{2 a}-\mathbf{f})(0.4 \mathrm{~g}, 1$ equiv) were dissolved in absolute ethanol $(3 \mathrm{~mL})$ and hydrazine monohydrate $(1.183 \mathrm{~mL}, 10$ equiv) was added into it. The reaction was refluxed and monitored by TLC. After the completion of the reaction, ethanol was evaporated. To the residue, ice-cold water $(10 \mathrm{~mL})$ was added and the organic layer was extracted with dichloromethane $(3 \times 20 \mathrm{~mL})$. The organic layer was further washed with saturated $\mathrm{NaCl}$ solution $(2 \times 10 \mathrm{~mL})$. The organic layer was dried over anhydrous $\mathrm{Na}_{2} \mathrm{SO}_{4}$ and the solvent was evaporated. Finally, the crude product was recrystallized (ethanol-water) to obtain the desired hydrazides in $80-85 \%$ yield.

4.4. General Procedure for the Synthesis of Hydrazide-Hydrazone Derivatives (5-34). To the solution of substituted benzoic acid hydrazides (3) ( $0.1 \mathrm{~g}, 1$ equiv) in absolute methanol $(1.5 \mathrm{~mL})$, different aromatic aldehydes (1 equiv) were added, followed by the addition of catalytic amount of $p$-toluenesulfonic acid $(p \mathrm{TsOH})$. After stirring for $2 \mathrm{~h}$ at room temperature, methanol was evaporated under reduced pressure. To the residue, aqueous $10 \% \mathrm{NaHCO}_{3}(10 \mathrm{~mL})$ was added and the organic layer was extracted with ethyl acetate (3 $\times 10 \mathrm{~mL}$ ) followed by washing with saturated $\mathrm{NaCl}$ solution $(2$ $\times 10 \mathrm{~mL}$ ). The organic layer was dried over anhydrous $\mathrm{Na}_{2} \mathrm{SO}_{4}$ and the solvent was evaporated. Final compounds were purified by using column chromatography on the basic aluminum oxide $\left(\mathrm{Al}_{2} \mathrm{O}_{3}\right)$ (ethyl acetate $/$ hexane $=20 \%$ ) to give hydrazidehydrazone derivatives in $70-80 \%$ yield.

4.5. HPLC Analysis. The purity of compound 28 was determined by reverse phase high-performance liquid chromatography (RP-HPLC) using a $4.6 \times 250 \mathrm{~mm} 5 \mu \mathrm{m}$ C18 column using acetonitrile/water with gradient for $10 \mathrm{~min}$. The sample $(20 \mu \mathrm{L})$ was injected (concentration $=1 \mathrm{mg} / \mathrm{mL}$ ) into the column with $1 \mathrm{~mL} / \mathrm{min}$ flow rate.

4.6. Cell Viability Assay. Five thousand colorectal cancer cells (DLD-1, HCT-116, and SW-620) were seeded per well in a 96-well plate for attachment. To screen all of the compounds, $3 \mathrm{mM}$ stock solutions of all of the compounds were prepared in dimethyl sulfoxide (DMSO). The cells were then treated with all of the compounds $(30 \mu \mathrm{M})$ for $24 \mathrm{~h}$. For calculation of $\mathrm{IC}_{50}$, the cells were treated with compound $\mathbf{2 8}$ in different concentrations $(0.1,0.2,0.4,0.8,1.6,3.2,6.4,12.5,25$, and $50 \mu \mathrm{M})$. Cell viability was determined by adopting the previously described procedure. $^{67}$

For fibroblast cells, 10000 L929 (murine lung fibroblast) cells were plated in each well of a 96-well plate and incubated in $5 \% \mathrm{CO}_{2}$ at $37{ }^{\circ} \mathrm{C}$ overnight. Drug dilutions were made in complete $10 \%$ fetal bovine serum (FBS)-containing DMEM media. Hundred microliter of each drug solutions (diluted in DMSO) was added in each well of the 96-well plate (in triplicates). Untreated cells (without any drug) were considered as control. After adding drugs, the cells were incubated for $24 \mathrm{~h}$. After $24 \mathrm{~h}$, media were aspirated and $100 \mu \mathrm{L}$ MTT reagent (10 $\mu \mathrm{L}$ of $5 \mathrm{mg} / \mathrm{mL}$ solution and $90 \mu \mathrm{L}$ sterile media) was added in each well. It was incubated for $3 \mathrm{~h}$. Finally, all of the media were aspirated. Formazan crystals were dissolved in $100 \mu \mathrm{L}$ DMSO and read in a plate reader having $550 \mathrm{~nm}$ cutoff filter. Percent cell death calculation data were normalized with untreated cells. Each data represent an average of 3 data points. Error calculated as standard error following (STDEV/(SQRT(3))) using Microsoft excel.

4.7. Confocal Laser Scanning Microscopy (CLSM). 1.5 $\times 10^{4}$ HCT-116 cells were seeded in each well in 8-well LabTek chamber slides for attachment. Compound $28(15 \mu \mathrm{M})$ was incubated with the cells for $24 \mathrm{~h}$. Control cells were not treated with any compound.

4.7.1. JC1 Assay. Cells were washed thoroughly with phosphate-buffered saline (PBS) followed by the addition of JC1 dye to incubate for $20 \mathrm{~min}$. The green and red fluorescently labeled cells were seen and quantified by confocal microscopy. ${ }^{68}$ 
4.7.2. Calcein AM Assay. After $24 \mathrm{~h}$, calcein AM $(1 \mu \mathrm{M})$ and $1 \mathrm{mM} \mathrm{CoCl}{ }_{2}$ were added into the cells, followed by imaging through confocal microscopy. ${ }^{68}$

4.7.3. Mitochondrial Morphology Assay. After $24 \mathrm{~h}$ of incubation with compound $\mathbf{2 8}$, the cells were washed thoroughly with PBS and stained with MitoTracker Red CMXRos for $20 \mathrm{~min}$. The cells were then treated with paraformaldehyde (4\%) for $10 \mathrm{~min}$ and visualized and quantified by CLSM. $^{67}$

4.7.4. ROS Generation by DCFH-DA Assay. After treatment with compound 28, the cells were then washed with PBS ( $\mathrm{pH}$ 7.4) and treated with DCFH-DA for $15 \mathrm{~min}$. Finally, the cells were washed thrice with $\mathrm{PBS}(\mathrm{pH} 7.4)$ and visualized by CLSM.

4.7.5. TMRM Assay. The cells were washed with cold PBS 3 times and treated with TMRM $(10 \mu \mathrm{M} / \mathrm{mL})$ for $30 \mathrm{~min}$. The cells were then washed with PBS ( $\mathrm{pH} 7.4)$ and imaged by CLSM to visualize mitochondrial damage.

4.7.6. Immunostaining To Visualize Cytochrome c. $5 \times 10^{4}$ HCT-116 cells were attached on the coverslip in a 6-well plate followed by incubation with compound $\mathbf{2 8}$ for $24 \mathrm{~h}$. The cells were thoroughly rinsed with PBS and fixed with paraformaldehyde (4\%) for $10 \mathrm{~min}$. The cells were then further washed and permeabilized by blocking buffer. The cells were then treated with cytochrome $c$ primary antibody solution (1:100 dilution) for $3 \mathrm{~h}$. After further washing with blocking buffer, the cells were treated with a Alexa Fluor 488 labeled secondary antibody solution (1:500 dilution) for $30 \mathrm{~min}$ in dark. Fluorescently labeled cells were visualized further by CLSM. ${ }^{67}$

4.7.7. Immunostaining To Visualize BCl-2. After treatment with compound 28, the cells were washed once with PBS and fixed with $3.7 \%$ paraformaldehyde at $37{ }^{\circ} \mathrm{C}$ for $15 \mathrm{~min}$. The cells were further washed twice with $\mathrm{PBS}(\mathrm{pH}=7.4)$ and permeabilized by incubating in blocking buffer (PBS containing $0.3 \%$ Tween and 5\% FBS) at room temperature. The cells were then incubated in Bcl-2 primary antibody (Santa Cruz Biotechnology, Inc.) in 1:100 dilution at $37^{\circ} \mathrm{C}$ for $3 \mathrm{~h}$. The cells were washed thrice with blocking buffer followed by incubation in Alexa Fluor 488 antimouse IgG secondary antibody solution (1:500 dilutions) at $37{ }^{\circ} \mathrm{C}$ for $40 \mathrm{~min}$ in the dark. The cells were washed thrice with PBS and mounted on a glass slide using SlowFade Gold antifade reagent. The slides were subjected to fluorescence imaging using CLSM.

4.8. General Procedure for Western Blot Analysis. $1 \times$ $10^{5}$ HCT-116 cells were treated with compound 28 for $24 \mathrm{~h}$ followed by cell lysis. Sodium dodecyl sulfate polyacrylamide gel electrophoresis was used to separate respective proteins and transferred them onto the membrane by electroblotting. The protein-containing membranes were blocked and incubated with primary antibodies for $24 \mathrm{~h}$ at $4{ }^{\circ} \mathrm{C}$. Further, the membrane was washed and incubated with secondary antibody for $1 \mathrm{~h}$ at $25^{\circ} \mathrm{C}$. Proteins were then detected and quantified by an ImageQuant LAS 4000 and an ImageJ software. ${ }^{67,68}$

4.9. Fluorescence-Activated Cell-Sorting (FACS) Assay. HCT-116 cells $\left(2 \times 10^{6}\right.$ cell per well $)$ were attached in 6-well plates and then treated with compound 28 for $24 \mathrm{~h}$ at $15 \mu \mathrm{M}$.

4.9.1. Apoptosis Detection. The cells were detached by using trypsin and washed with PBS. The suspended cells were then incubated with Annexin V-FITC Staining Kit using the manufacturer's protocol. The apoptotic and necrotic cells were quantified by using a BD Accuri c6 flow cytometer. ${ }^{67}$
4.9.2. Cell Cycle Analysis. After treatment with compound 28, the cells were then harvested and washed with $1 \mathrm{~mL}$ PBS $(\mathrm{pH}=7.4)$ and centrifuged at $850 \mathrm{rpm}$ for $4 \mathrm{~min}$. After discarding the supernatant, the cells was fixed with cold $70 \%$ EtOH for 0.5 h. The cells were washed thoroughly with PBS, followed by the addition of $500 \mu \mathrm{L}$ staining solution. A BD Accuri C6 flow cytometer was used for cell cycle analysis. ${ }^{67}$

\section{ASSOCIATED CONTENT}

\section{Supporting Information}

The Supporting Information is available free of charge on the ACS Publications website at DOI: 10.1021/acsomega.7b01512.

Characterization data for all of the library members (compounds 5-34), NMR $\left({ }^{1} \mathrm{H}\right.$ and $\left.{ }^{13} \mathrm{C}\right)$ and HR-MS spectra of all of the library members (compounds 5-34), cell viability data, RP-HPLC data, MALDI-TOF spectra, JC1 assay quantification, confocal laser scanning microscopy images, and protein quantification from gel electrophoresis (PDF)

\section{AUTHOR INFORMATION}

\section{Corresponding Author}

*E-mail: sudipta.basu@iiserpune.ac.in.

ORCID

Sudipta Basu: 0000-0002-0433-8899

Notes

The authors declare no competing financial interest.

\section{ACKNOWLEDGMENTS}

S.B. sincerely acknowledges the financial support from the Department of Biotechnology (Ramalingaswami Fellowship: BT/RLF/Re-entry/13/2011, BT/PR9918/NNT/28/692/ 2013, and BT/PR14724/NNT/28/831/2015). S. Patil and S. Palvai are thankful to the CSIR-UGC for doctoral fellowship. P.S. is thankful to the DST Women Scientist Scheme-A (SR/ WOS-A/CS94/2012) for funding, fellowship, and Academy of Scientific \& Innovative Research (AcSIR) for Ph.D. registration. We thank Mr. Amol Gade from CSIR-NCL for helping in HPLC experiment. We also acknowledge Dr. Nirmalya Ballav, IISER, Pune, for stimulating scientific discussion.

\section{REFERENCES}

(1) American Cancer Society. Colorectal Cancer Facts \& Figures 2011-2013; American Cancer Society: Atlanta, 2011.

(2) Ferlay, J.; Soerjomataram, I.; Ervik, M.; Dikshit, R.; Eser, S.; Mathers, C.; Rebelo, M.; Parkin, D. M.; Forman, D.; Bray, F. GLOBOCAN 2012, v1.0, Cancer Incidence and Mortality Worldwide: IARC Cancer Base No. 11, 2012. http://globocan.iarc.fr.

(3) Rubbia-Brandt, L.; Audard, V.; Sartoretti, P.; Roth, A. D.; Brezault, C.; Le Charpentier, M.; Dousset, B.; Morel, P.; Soubrane, O.; Chaussade, S.; Mentha, G.; Terris, B. Severe hepatic sinusoidal obstruction associated with oxaliplatin-based chemotherapy in patients with metastatic colorectal cancer. Ann. Oncol. 2004, 15, 460-466.

(4) André, T.; Boni, C.; Mounedji-Boudiaf, L.; Navarro, M.; Tabernero, J.; Hickish, T.; Topham, C.; Zaninelli, M.; Clingan, P.; Bridgewater, J.; Tabah-Fisch, I.; de Gramont, A. Oxaliplatin, Fluorouracil, and Leucovorin as Adjuvant Treatment for Colon Cancer. N. Engl. J. Med. 2004, 350, 2343-2351.

(5) Klotz, H. P.; Weder, W.; Largiadèr, F. Local and systemic toxicity of intra-hepatic-arterial 5-FU and high-dose or low-dose leucovorin for liver metastases of colorectal cancer. Surg. Oncol. 1994, 3, 11-16.

(6) Knight, Z. A.; Lin, H.; Shokat, K. M. Targeting the cancer kinome through polypharmacology. Nat. Rev. Cancer 2010, 10, 130-137. 
(7) Wilson, T. R.; Fridlyand, J.; Yan, Y.; Penuel, E.; Burton, L.; Chan, E.; Peng, J.; Lin, E.; Wang, Y.; Sosman, J.; Ribas, A.; Li, J.; Moffat, J.; Sutherlin, D. P.; Koeppen, H.; Merchant, M.; Neve, R.; Settleman, J. Widespread potential for growth-factor-driven resistance to anticancer kinase inhibitors. Nature 2012, 487, 505-509.

(8) Gottesman, M. M.; Fojo, T.; Bates, S. E. Multidrug resistance in cancer: role of ATP-dependent transporters. Nat. Rev. Cancer 2002, 2, $48-58$.

(9) Holohan, C.; Van Schaeybroeck, S.; Longley, D. B.; Johnston, P. G. Cancer drug resistance: an evolving paradigm. Nat. Rev. Cancer 2013, 13, 714-726.

(10) Trifunovic, A.; Wredenberg, A.; Falkenberg, M.; Spelbrink, J. N.; Rovio, A. T.; Bruder, C. E.; Bohlooly, M.; Gidlöf, S.; Oldfors, A.; Wibom, R.; Törnell, J.; Jacobs, H. T.; Larsson, N. Premature ageing in mice expressing defective mitochondrial DNA polymerase. Nature 2004, 429, 417-423.

(11) Smith, R. A. J.; Hartley, R. C.; Cochemé, H. M.; Murphy, M. P. Mitochondrial pharmacology. Trends Pharmacol. Sci. 2012, 33, 341352.

(12) Ward, P. S.; Thompson, C. B. Metabolic reprogramming: a cancer hallmark even warburg did not anticipate. Cancer Cell 2012, 21, 297-308.

(13) Chandel, N. S. Mitochondria as signaling organelles. BMC Biol. 2014, 12, 34-40.

(14) Galluzzi, L.; Oliver, K.; Guido, K. Mitochondria: master regulators of danger signalling. Nat. Rev. Mol. Cell Biol. 2012, 13, 780788.

(15) Tait, S. W. G.; Green, D. R. Mitochondria and cell death: outer membrane permeabilization and beyond. Nat. Rev. Mol. Cell Biol. 2010, 11, 621-632.

(16) Calvo, S. E.; Mootha, V. K. The mitochondrial proteome and human disease. Annu. Rev. Genomics Hum. Genet. 2010, 11, 25-44.

(17) Nunnari, J.; Suomalainen, A. Mitochondria: in sickness and in health. Cell 2012, 148, 1145-1159.

(18) Gogvadze, V.; Orrenius, S.; Zhivotovsky, B. Mitochondria in cancer cells: what is so special about them? Trends Cell Biol. 2008, 18, 165-173.

(19) Boroughs, L. K.; DeBerardinis, R. J. Metabolic pathways promoting cancer cell survival and growth. Nat. Cell Biol. 2015, 17, 351-359.

(20) Fulda, S.; Galluzzi, L.; Kroemer, G. Targeting mitochondria for cancer therapy. Nat. Rev. Drug Discovery 2010, 9, 447-464.

(21) Weinberg, S. E.; Chandel, N. S. Targeting mitochondria metabolism for cancer therapy. Nat. Chem. Biol. 2015, 11, 9-15.

(22) Wallace, D. C. Mitochondria and cancer. Nat. Rev. Cancer 2012, $12,685-698$.

(23) Vyas, S.; Zaganjor, E.; Haigis, M. C. Mitochondria and Cancer. Cell 2016, 166, 555-566.

(24) Marrache, S.; Pathaka, R. K.; Dhar, S. Detouring of cisplatin to access mitochondrial genome for overcoming resistance. Proc. Natl. Acad. Sci. U.S.A. 2014, 111, 10444-10449.

(25) Marrache, S.; Dhar, S. Engineering of blended nanoparticle platform for delivery of mitochondria-acting therapeutics. Proc. Natl. Acad. Sci. U.S.A. 2012, 109, 16288-16293.

(26) Jean, S. R.; Ahmed, M.; Lei, E. K.; Wisnovsky, S. P.; Kelley, S. O. Peptide-Mediated Delivery of Chemical Probes and Therapeutics to Mitochondria. Acc. Chem. Res. 2016, 49, 1893-1902.

(27) Wisnovsky, S.; Lei, E. K.; Jean, S. R.; Kelley, S. O. Mitochondrial Chemical Biology: New Probes Elucidate the Secrets of the Powerhouse of the Cell. Cell Chem. Biol. 2016, 23, 917-927.

(28) Jean, S. R.; Tulumello, D. V.; Wisnovsky, S. P.; Lei, E. K.; Pereira, M. P.; Kelley, S. O. Molecular vehicles for mitochondrial chemical biology and drug delivery. ACS Chem. Biol. 2014, 9, 323333.

(29) Chatterjee, A.; Mambo, E.; Sidransky, D. Mitochondrial DNA mutations in human cancer. Oncogene 2006, 25, 4663-4674.

(30) Sánchez-Aragó, M.; Chamorro, M.; Cuezva, J. M. Selection of cancer cells with repressed mitochondria triggers colon cancer progression. Carcinogenesis 2010, 31, 567-576.
(31) Hübel, K.; Leßmann, T.; Waldmann, H. Chemical biologyidentification of small molecule modulators of cellular activity by natural product inspired synthesis. Chem. Soc. Rev. 2008, 37, 13611374.

(32) Schreiber, S. L. Target-oriented and diversity-oriented organic synthesis in drug discovery. Science 2000, 287, 1964-1969.

(33) DeVita, V. T., Jr.; Chu, E. A History of cancer chemotherapy. Cancer Res. 2008, 68, 8643-8653.

(34) Ziegler, S.; Pries, V.; Hedberg, C.; Waldmann, H. Target identification for small bioactive molecules: finding the needle in the haystack. Angew. Chem., Int. Ed. 2013, 52, 2744-2792.

(35) Škrtić, M.; Sriskanthadevan, S.; Jhas, B.; Gebbia, M.; Wang, X.; Wang, Z.; Hurren, R.; Jitkova, Y.; Gronda, M.; Maclean, N.; Lai, C. K.; Eberhard, Y.; Bartoszko, J.; Spagnuolo, P.; Rutledge, A. C.; Datti, A.; Ketela, T.; Moffat, J.; Robinson, B. H.; Cameron, J. H.; Wrana, J.; Eaves, C. J.; Minden, M. D.; Wang, J. C.; Dick, J. E.; Humphries, K.; Nislow, C.; Giaever, G.; Schimmer, A. D. Inhibition of mitochondrial translation as a therapeutic strategy for human acute myeloid leukemia. Cancer Cell 2011, 20, 674-688.

(36) Wang, D.; Wang, J.; Bonamy, G. M. C.; Meeusen, S.; Brusch, R. G.; Turk, C.; Yang, P.; Schultz, P. G. A small molecule promotes mitochondrial fusion in mammalian cells. Angew. Chem., Int. Ed. 2012, $51,9302-9305$

(37) Leanza, L.; Romio, M.; Becker, K. A.; Azzolini, M.; Trentin, L.; Managò, A.; Venturini, E.; Zaccagnino, A.; Mattarei, A.; Carraretto, L.; Urbani, A.; Kadow, S.; Biasutto, L.; Martini, V.; Severin, F.; Peruzzo, R.; Trimarco, V.; Egberts, J. H.; Hauser, C.; Visentin, A.; Semenzato, G.; Kalthoff, H.; Zoratti, M.; Gulbins, E.; Paradisi, C.; Szabo, I. Direct pharmacological targeting of a mitochondrial ion channel selectively kills tumor cells in vivo. Cancer Cell 2017, 31, 516-531.

(38) Goff, G. L.; Ouazzani, J. Natural hydrazine-containing compounds: biosynthesis, isolation, biological activities and synthesis. Bioorg. Med. Chem. 2014, 22, 6529-6544.

(39) Blair, L. M.; Sperry, J. Natural products containing a nitrogennitrogen bond. J. Nat. Prod. 2013, 76, 794-812.

(40) Trosset, J. Y.; Dalvit, C.; Knapp, S.; Fasolini, M.; Veronesi, M.; Mantegani, S.; Gianellini, L. M.; Catana, C.; Sundström, M.; Stouten, P. F.; Moll, J. K. Inhibition of protein-protein interactions: the discovery of druglike beta-catenin inhibitors by combining virtual and biophysical screening. Proteins 2006, 64, 60-67.

(41) Das Mukherjee, D.; Kumar, N. M.; Tantak, M. P.; Das, A.; Ganguli, A.; Datta, S.; Kumar, D.; Chakrabarti, G. Development of novel bis(indolyl)-hydrazide-hydrazone derivatives as potent microtubule-targeting cytotoxic agents against A549 lung cancer cells. Biochemistry 2016, 55, 3020-3035.

(42) Nasr, T.; Bondock, S.; Youns, M. Anticancer activity of new coumarin substituted hydrazide-hydrazone derivatives. Eur. J. Med. Chem. 2014, 76, 539-548.

(43) Vogel, S.; Kaufmann, D.; Pojarová, M.; Müller, C.; Pfaller, T.; Kühne, S.; Bednarski, P. J.; von Angerer, E. Aroyl hydrazones of 2phenylindole-3-carbaldehydes as novel antimitotic agents. Bioorg. Med. Chem. 2008, 16, 6436-6447.

(44) Liu, T.; Sun, C.; Xing, X.; Jing, L.; Tan, R.; Luo, Y.; Huang, W.; Song, H.; Li, Z.; Zhao, Y. Synthesis and evaluation of 2-[2(phenylthiomethyl)-1H-benzo[d] imidazol-1-yl)acetohydrazide derivatives as antitumor agents. Bioorg. Med. Chem. Lett. 2012, 22, 31223125.

(45) Cui, Z.; Li, Y.; Ling, Y.; Huang, J.; Cui, J.; Wang, R.; Yang, X. New class of potent antitumor acylhydrazone derivatives containing furan. Eur. J. Med. Chem. 2010, 45, 5576-5584.

(46) Popiołek, Ł. Hydrazide-hydrazones as potential antimicrobial agents: overview of the literature since 2010. Med. Chem. Res. 2017, 26, 287-301.

(47) Hughes, J. P.; Rees, S.; Kalindjian, S. B.; Philpott, K. L. Principles of early drug discovery. Br. J. Pharmacol. 2011, 162, 12391249.

(48) Vrijens, K.; Lin, W.; Cui, J.; Farmer, D.; Low, J.; Pronier, E.; Zeng, F. Y.; Shelat, A. A.; Guy, K.; Taylor, M. R.; Chen, T.; Roussel, 
M. F. Identification of small molecule activators of BMP signalling.

PLoS One 2013, 8, No. e59045.

(49) Kalia, J.; Raines, R. T. Hydrolytic stability of hydrazones and oximes. Angew. Chem., Int. Ed. 2008, 47, 7523-7526.

(50) Hanahan, D.; Weinberg, R. A. The hallmarks of cancer. Cell 2000, 100, 57-70.

(51) Hanahan, D.; Weinberg, R. A. Hallmarks of cancer: the next generation. Cell 2011, 144, 646-674.

(52) Green, D. R.; Kroeme, G. The pathophysiology of mitochondrial cell death. Science 2004, 305, 626-629.

(53) Chipuk, J. E.; Green, D. R. How do BCL-2 proteins induce mitochondrial outer membrane permeabilization? Trends Cell Biol. 2008, 18, 157-164.

(54) Chipuk, J. E.; Bouchier-Hayes, L.; Green, D. R. Mitochondrial outer membrane permeabilization during apoptosis: the innocent bystander scenario. Cell Death Differ. 2006, 13, 1396-1402.

(55) Cossarizza, A.; Baccaranicontri, M.; Kalashnikova, G.; Franceschi, C. A new method for the cytofluorimetric analysis of mitochondrial membrane potential using the J-aggregate forming lipophilic cation 5,5',6,6'-tetrachloro-1,1',3,3'-tetraethylbenzimidazolcarbocyanine iodide (JC-1). Biochem. Biophys. Res. Commun. 1993, 197, 40-45.

(56) Petronilli, V.; Miotto, G.; Canton, M.; Brini, M.; Colonna, R.; Bernardi, P.; Lisa, F. D. Transient and long-lasting openings of the mitochondrial permeability transition pore can be monitored directly in intact cells by changes in mitochondrial calcein fluorescence. Biophys. J. 1999, 76, 725-734.

(57) Floryk, D.; Houštěk, J. Tetramethyl rhodamine methyl ester (TMRM) is suitable for cytofluorometric measurements of mitochondrial membrane potential in cells treated with digitonin. Biosci. Rep. 1999, 19, 27-34.

(58) Dagda, R. K.; Cherra, S. J.; Kulich, S. M.; Tandon, A.; Park, D.; Chu, C. T. Loss of PINK1 function promotes mitophagy through effects on oxidative stress and mitochondrial fission. J. Biol. Chem. 2009, 284, 13843-13855.

(59) Ashkenazi, A.; Fairbrother, W. J.; Leverson, J. D.; Souers, A. J. From basic apoptosis discoveries to advanced selective BCL-2 family inhibitors. Nat. Rev. Drug Discovery 2017, 16, 273-284.

(60) Jiang, X.; Wang, X. Cytochrome C-mediated apoptosis. Annu. Rev. Biochem. 2004, 73, 87-106.

(61) Wu, D.; Yotnda, P. Production and detection of reactive oxygen species (ROS) in cancers. J. Visualized Exp. 2011, No. e3357.

(62) Koczor, C. A.; Shokolenko, I. N.; Boyd, A. K.; Balk, S. P.; Wilson, G. L.; LeDoux, S. P. Mitochondrial DNA damage initiates a cell cycle arrest by a Chk2-associated mechanism in mammalian cells. J. Biol. Chem. 2009, 284, 36191-36201.

(63) Mariño, G.; Niso-Santano, M.; Baehrecke, E. H.; Kroemer, G. Self-consumption: the interplay of autophagy and apoptosis. Nat. Rev. Mol. Cell Biol. 2014, 15, 81-94.

(64) Li, P.; Nijhawan, D.; Budihardjo, I.; Srinivasula, S. M.; Ahmad, M.; Alnemri, E. S. X.; Wang, X. Cytochrome c and dATP-dependent formation of Apaf-1/caspase-9 complex initiates an apoptotic protease cascade. Cell 1997, 91, 479-489.

(65) Vaseva, A. V.; Moll, U. M. The mitochondrial p53 pathway. Biochim. Biophys. Acta 2009, 1787, 414-420.

(66) Jiang, M.; Milner, J. Bcl-2 constitutively suppresses p53dependent apoptosis in colorectal cancer cells. Genes Dev. 2003, 17, 832-837.

(67) Mallick, A.; More, P.; Ghosh, S.; Chippalkatti, R.; Chopade, B. A.; Lahiri, M.; Basu, S. Dual drug conjugated nanoparticle for simultaneous targeting of mitochondria and nucleus in cancer cells. ACS Appl. Mater. Interfaces 2015, 7, 7584-7598.

(68) Mallick, A.; More, P.; Syed, M. M.; Basu, S. Nanoparticlemediated mitochondrial damage induces apoptosis in cancer. ACS Appl. Mater. Interfaces 2016, 8, 13218-13231. 